\title{
ENGLISH ETYMOLOGY
}

A SELECT GLOSSARY

SERVING AS AN INTRODUCTION TO THE HISTORY

OF THE ENGLISH LANGUAGE

BY

\section{FRIEDRICH KLUGE}

PROFESSOR OF THE GERMAN LANGUAGE AND LITERATURE AT THE

UNIVERSITY OF FREIBURG IN BADEN, GERMANY

AND

\section{FREDERICK LUTZ}

PROFESSOR OF MODERN LANGUAGES AT ALBION COLLEGE, MichigaN

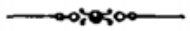

BOSTON, U.S.A.

D. C. HEATH \& CO., PUBLISHERS 
